\title{
University faces up to wartime use of slaves
}

Alison Abbott, Munich

After two years of bickering, the University of Göttingen has given the go-ahead for a project to establish the fate of slave labourers employed and treated at its medical faculty under the Third Reich.

The university has also agreed to publish a summary of the findings of an initial investigation led by historian Andreas Frewer, who delivered his report to the faculty's board last June. And it is calling for donations from staff and students to an existing compensation fund for the slave labourers.

Frewer has long been at loggerheads with the board of the medical school, claiming that its members have hindered his work. He was appointed by the university's Department of Medical Ethics and History of Medicine at the beginning of 2000 , with a brief to investigate whether or not the university clinics had exploited slave labour, as many

industrial employers did during the Second World War.

In his initial study, Frewer and his colleagues located files from the university's surgical and gynaecological wards, and identified 125 slave labourers who had worked within the faculty between 1940 and 1945 . They also found details of some 600 slave labourers who were treated in the wards.

The records were used as evidence by some former slave labourers who applied to a federal compensation fund that was established in Germany in 1999.

But Frewer was denied access to neurological and psychiatric files on the patients, which were kept by a private company. Moreover, he claims, the faculty board obstructed his path, slowing down the publication of his results, limiting the amount of assistance that he received, and failing to respond to requests for meetings. The board

\section{Atlantic cod meet icy death}

\section{Hannah Hoag, Washington}

More than 700 tonnes of Atlantic cod have frozen to death in chilly waters off eastern Newfoundland.

The dead fish first began to surface in the waters of Smith Sound, Trinity Bay, on 3 April, but scientists are struggling to explain what induced the cod to swim into the lethal waters.

Such mass culls are very rare, although one in the northeastern United States killed an estimated 10 million to 100 million 'warm water' tilefish fish in 1882 (R. Marsh et al. Fish Oceanogr. 8, 39-49; 1999).

At this time of year, cod are usually found in warmer waters near the bay. Local theories on why they entered the sound include a bid to escape from seals and a fateful pursuit of herring. But none of these ideas passes muster, says George Lilly, a biologist with Canada's Department of Fisheries and Oceans (DFO), who is investigating the deaths.

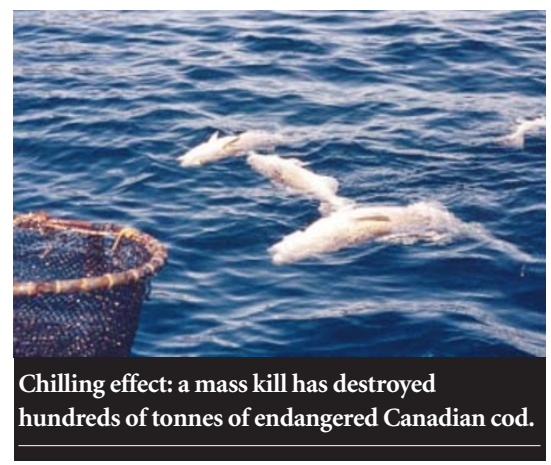

A team of biologists and oceanographers from local universities and the DFO has been monitoring water temperature, salinity and oxygen saturation in the sound since last week. They have also collected dead cod for analysis and confirmed that they were perfectly healthy when frozen. They have used acoustic and video monitoring equipment to track down survivors.

In early April the temperature of the water column in Smith Sound fell to $-1.7^{\circ} \mathrm{C}$, says Eugene Colbourne, an oceanographer with the DFO. Historical temperature profiles from the region indicate that such temperatures are very unusual for the sound.

Cod produce antifreeze proteins in their blood to safeguard them from very cold water, but the proteins take two months to build up to maximum levels and the dead fish had very little of them in their blood, say investigators.

Some environmentalists are describing the mass kill as an environmental disaster, as it destroyed one of the last remnants of the region's few cod stocks.

Canada's fisheries minister, Robert Thibault, is expected to make an announcement shortly on Newfoundland's fisheries, and may ban cod fishing. Cod used to make up $70-80 \%$ of the total stock in the province, says Jeffrey Hutchings, an evolutionary biologist at Dalhousie University in Halifax, Nova Scotia, but $\mathbf{9 9 . 9 \%}$ of the stock has been lost. North Atlantic cod is classed as being of 'special concern' by the Committee on the Status of Endangered Wildlife in Canada.

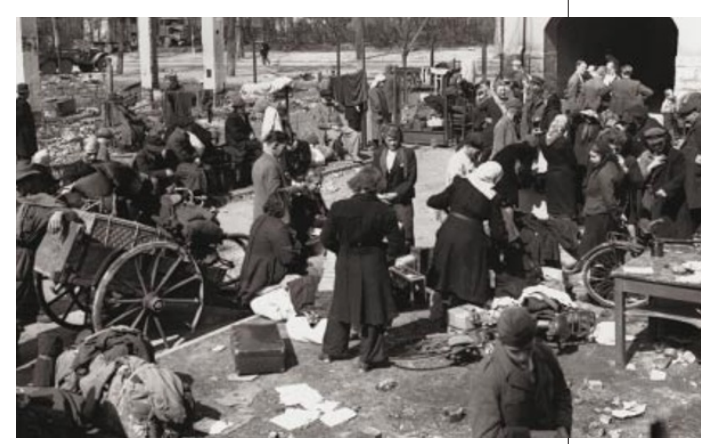

Slavery in Wurzburg, 1945: university historians are now unearthing its true extent in Germany.

also delayed and watered down press releases about the results, he alleges, and failed to respond to the project's final report.

Frewer argues that if the medical faculty had been more dedicated to the project, many more of the slave labourers - whose numbers are now rapidly dwindling - would have been able to claim compensation from a state fund, which is now no longer accepting claims. He also criticizes the faculty for not contributing to the federal fund.

The project's difficulties have also been noted by outsiders. Ernst Böhme, head of the Göttingen City Archive, which has also sought and supplied documents to support compensation claims by former slave labourers, says that the historical research at the medical faculty seems to have been proceeding too slowly.

But Manfred Droese, dean of the faculty, denies that he or his board sought to hinder the project or to block discussions of its results. "Maybe we caused a bit of delay, but I started the project because we wanted to face the faculty's history," he argues. He adds, however, that the project should have concentrated on documenting the employment of slave labourers, rather than devoting effort to assisting compensation claims.

The neurological and psychiatric files contain sensitive information about people who could still be alive, Droese says, and their examination had to be approved by experts in data-protection law. But he says that the files will now be made available for a new research project.

According to Claudia Wiesemann, director of the university's ethics department, the new project will have a broader scope in looking for what happened generally to slave labourers in psychiatric and neurological clinics, and will attempt to determine how many were sterilized or killed.

Droese describes Frewer as 'self-righteous', but Frewer's supporters say that it is only his perseverance that has forced the faculty board to move the research forward. 